\title{
Integration of physical and chemical treatment on the extraction of starch from Canna edulis Ker. rhizome
}

\author{
Judy R. B. Witono*, Herry Santoso, Y. I. P. Arry Miryanti, Daniel Tan
}

Chemical Engineering Department, Parahyangan Catholic University, Bandung, Indonesia;

*Corresponding Author: judy@unpar.ac.id

Received August 2013

\begin{abstract}
The extraction of Canna edulis Ker. starch from its rhizome was performed using 2 different types of press (hydraulic press and screw press) and with the addition of Na-metabisulphite and $\mathrm{NaOH}$ (in the range of concentration $100-5000$ ppm each). The optimum condition for this process was determined by Central Composite Design of experiment and the statistical calculation was solved by Design-Expert 7.0.0. The targets of the observed responses were high starch yield, low ash, low fiber, and high carbohydrate content. The results showed that the starch yield and the reduction of fiber were only influenced by the physical treatment whereas ash content in the product was influenced by both the $\mathrm{NaOH}$ concentration and physical treatment. The carbohydrate content in the extraction product was affected by $\mathrm{NaOH}$, by the interaction between the concentrations of $\mathrm{NaOH}$ and $\mathrm{Na}_{2} \mathrm{~S}_{2} \mathrm{O}_{5}$ and also by the physical treatment. The hydraulic press gives much better responses compared to the screw press. But in the selected range of additives concentrations, the screw press gives a higher starch yield (30\% $52 \%)$.
\end{abstract}

Keywords: Canna edulis Ker.; Central Composite Design of Experiment; Hydraulic Press; Screw Press; Starch Extraction

\section{INTRODUCTION}

One of the tropical starch resources which have not been utilized for industrial application is Canna edulis Ker. rhizome, partly because of the difficulties in the extraction processing [1]. The high content of fiber and other trace elements are a major constraint in producing pure starch. A sample of $100 \mathrm{~g}$ of Canna edulis rhizome contains $125 \mathrm{mg}$ phosphorus (P), $84 \mathrm{mg}$ calcium (Ca) and
$1.5 \mathrm{mg}$ iron (Fe) mineral [2]. The presence of those elements in food products can be categorized as a nutritional value but it will be a disadvantage for a chemical starchbased product.

Salt solutions like $\mathrm{NaCl}$, Na-bisulphite, and Na-metabisulphite are commonly used during extraction of starch from its natural source, to inhibit microbial growth and deactivate plant enzyme (amylase). The salt solution can dissolve the surface starch granule protein as well, but for the breakdown of the integral starch granule protein, stronger solutions are required, e.g. sodium dodecyl sulphate (SDS) [3,4] or alkaline solutions [5].

Lim et al. [6] have investigated that the use of $0.2 \%$ of $\mathrm{NaOH}$ as an extraction solution for rice starch could reduce more than $80 \%$ of the flour protein. This was confirmed also by Radosavljevic et al. [7] on the extraction of Amaranth starch; Mistry et al. [8] on the extraction of corn flour using $0.1 \%$ and $0.4 \%$ of $\mathrm{NaOH}$. It was investigated also that sodium hydroxide $(\mathrm{NaOH})$ can remove phosphorus up to $70 \%$ - 90\% from wheat starch [9].

Since the properties of starch are, to some extent, different from the fiber (cellulose), a relatively low cost method for isolation of the starch is physical treatment. The goal of the research reported here is to determine the optimum condition of the integration of physical and chemical treatments in producing pure starch. For this purpose, a Central Composite Experimental Design method (CCD) was applied, statistical calculations were made using Design expert 7.0.0 software.

\section{MATERIALS \& METHODS}

\subsection{Materials}

Freshly harvested Canna edulis Ker. rhizome (locally known as Ganyong) was supplied by the farmers union "Mekar Sari" at the Kulon Progo region (Central Java) Indonesia. Analytical grade of sodium metabisulphite and $\mathrm{NaOH}$ were purchased from Sigma Aldrich. $\alpha$-amylase was supplied by Novozyme and Anthrone reagent by Merck. 


\subsection{Design of the Experiment}

To determine the optimum condition from 2 numerical factors (the Na-metabisulphite and $\mathrm{NaOH}$ concentrations) and 1 categorial factor (type of mechanical treatment or type of press instrument), the Central Composite Design was applied. This results in 26 runs with variations as shown in Table 1.

\subsection{Starch Extraction}

Fresh Canna edulis was peeled and washed, then milled with a cross beater mill. The pulp was mixed with water at a weight ratio 1:10. Half of mixture was filtered with the hydraulic press and the rest with the screw press, to separate the crude fiber.

The free crude fiber mixture which consists of the filtrate from each press was divided into 13 portions that were mixed with different concentrations of Na-metabisulphite and $\mathrm{NaOH}$ solutions as stated Table 1. After 12 hours the precipitated starch was separated from the liquor and dried in a tray drier for about 12 hours at $45^{\circ} \mathrm{C}$ until constant weight. The dried starch was kept in closed containers to be analyzed further.

Table 1. Overview of experimental runs.

\begin{tabular}{|c|c|c|c|}
\hline & Factor 1 & Factor 2 & Factor 3 \\
\hline Run & {$\left[\mathrm{Na}_{2} \mathrm{~S}_{2} \mathrm{O}_{5}\right]$} & [NaOH] & Type of treatment ${ }^{*}$ \\
\hline & ppm & $\mathrm{ppm}$ & \\
\hline 1 & 2550 & 2550 & Level 2 \\
\hline 2 & 2550 & 2550 & Level 2 \\
\hline 3 & 100 & 100 & Level 2 \\
\hline 4 & 2550 & 2550 & Level 1 \\
\hline 5 & 2550 & 2550 & Level 2 \\
\hline 6 & 5000 & 100 & Level 2 \\
\hline 7 & 100 & 5000 & Level 1 \\
\hline 8 & 2550 & 2550 & Level 2 \\
\hline 9 & 5000 & 5000 & Level 2 \\
\hline 10 & 5000 & 5000 & Level 1 \\
\hline 11 & 2550 & 2550 & Level 1 \\
\hline 12 & 100 & 2550 & Level 1 \\
\hline 13 & 100 & 2550 & Level 2 \\
\hline 14 & 2550 & 2550 & Level 1 \\
\hline 15 & 5000 & 2550 & Level 1 \\
\hline 16 & 5000 & 2550 & Level 2 \\
\hline 17 & 2550 & 2550 & Level 1 \\
\hline 18 & 2550 & 2550 & Level 1 \\
\hline 19 & 2550 & 5000 & Level 2 \\
\hline 20 & 2550 & 2550 & Level 2 \\
\hline 21 & 100 & 5000 & Level 2 \\
\hline 22 & 100 & 100 & Level 1 \\
\hline 23 & 2550 & 100 & Level 1 \\
\hline 24 & 2550 & 5000 & Level 1 \\
\hline 25 & 2550 & 100 & Level 2 \\
\hline 26 & 5000 & 100 & Level 1 \\
\hline
\end{tabular}

*Level 1—hydraulic press and level 2—screw press.

\subsection{Fiber Content}

The fiber content was measured by heating a mixture of $5 \mathrm{~g}$ of starch and $50 \mathrm{~mL}$ of water until $90^{\circ} \mathrm{C}$. Then 4 $\mathrm{mL}$ of $\alpha$-amylase enzyme was added and the total was kept at $90^{\circ} \mathrm{C}$ for a further 30 minutes. After that $50 \mathrm{~mL}$ of water was added and the sample was cooled to room temperature.

This method was based on the characteristic property of the $\alpha$-amylase enzyme which degrades carbohydrates to produce shorter chain molecules such as glucose, which is soluble in water. The cooled mixture was filtered using Whatman 42 filter paper under vacuum conditions to separate the fine fiber. The Fiber content (FC) was calculated using Eq.1.

$$
\mathrm{FC}(\%)=\frac{\mathrm{w}_{1}}{\mathrm{w}_{2}} \times 100 \%
$$

Where $\mathrm{w}_{1}$ is the weight of fine fiber and $\mathrm{w}_{2}$ is the weight of starch sample (dry basis).

\subsection{Ash Content}

Ash content measurement was also based on a gravimetric technique. $1 \mathrm{~g}$ of starch sample was combusted in a furnace at $600^{\circ} \mathrm{C}$ for 1 hour then cooled in desiccator and weight. This step was repeated until the weight was constant. Ash content (AC) was calculated using Eq.2.

$$
\mathrm{AC}(\%)=\frac{\mathrm{w}_{3}}{\mathrm{w}_{4}} \times 100
$$

Where $\mathrm{w}_{3}$ is the weight of ash and $\mathrm{w}_{4}$ is the weight of starch sample (dry basis).

\subsection{Carbohydrate Content}

The carbohydrate content was analyzed by anthrone reagent [10]. The anthrone method was started by making a standard graph which was made by diluting $10 \mathrm{mg}$ of glucose into $100 \mathrm{~mL}$ of water. The standards solution was taken $0,0.2,0.4,0.6,0.8$ and $1 \mathrm{~mL}(0$ serves as blank) and made up to $1 \mathrm{~mL}$ with distilled water. Then 4 $\mathrm{mL}$ of anthrone reagent was added.

Anthrone reagent was made by diluting $200 \mathrm{mg}$ anthrone in $100 \mathrm{~mL}$ of ice-cold $95 \% \mathrm{H}_{2} \mathrm{SO}_{4}$. All of the standard solutions were heated for eight minutes in a boiling water bath and then cooled rapidly. Carbohydrate content was measured with a spectrophotometer at $595 \mathrm{~nm}$ wavelength. A calibration graph was made by plotting concentrations of the standard solution on the X-axis against and the absorbance on the Y-axis.

Starch must be hydrolyzed prior to the treatment with anthrone solution. Therefore, $100 \mathrm{mg}$ of a sample of starch with $5 \mathrm{~mL}$ of $2.5 \mathrm{~N} \mathrm{HCl}$ added, was boiled in a water bath for three hours. When sample temperature 
was back to room temperature, it was neutralized with solid sodium carbonate $\left(\mathrm{Na}_{2} \mathrm{CO}_{3}\right)$ until the effervescence ceases. The solution was then made up to $100 \mathrm{~mL}$ and centrifuged and $0.1 \mathrm{~mL}$ of the supernatant was used for analysis. The rest of the procedure is the same for the standard solution. The amount of carbohydrate (CC) in the sample tube was then calculated from the absorbance in the spectrophotometer and the calibration graph by Eq.3.

$$
\mathrm{CC}(\%)=\frac{0.9 \times[\mathrm{C}] \times 1000}{\mathrm{w}_{5}} \times 100
$$

where [C] is the glucose concentration measured from the calibration graph whereas $\mathrm{w}_{5}$ is the weight of starch sample (dry basis).

\subsection{Starch Yield}

Starch yield was measured by comparing the weight of obtained starch (dry basis.) with the weight of dry matter sample (Canna edulis rhizome). The starch has been free from dirt 100. Starch Yield (SY) was determined by Eq.4.

$$
\mathrm{SY}(\%)=\frac{\mathrm{w}_{6}}{\mathrm{w}_{7}} \times 100
$$

where $\mathrm{w}_{6}$ is the weight starch (d.b.) whereas $\mathrm{w}_{7}$ is the weight of the dry matter original sample.

\section{RESULTS AND DISCUSSION} ble 2.

The analysis results from every run can be seen in Ta-

\subsection{Starch Yield}

Based on the ANOVA of the values obtained for the starch yield (Table 3 ) it can be seen that the additives concentrations, both $\mathrm{Na}_{2} \mathrm{~S}_{2} \mathrm{O}_{5}$ and $\mathrm{NaOH}$ do not affect the yield of starch. This is also proved by the probability value ( $\mathrm{P}$ value) from both additives which are above 0.005. The yield obtained is apparently more determined by the method of physical treatment.

Between the two types of press used, the higher starch yield was found when the screw press was used for separation (30\% - 52\%) compared to the hydraulic press (25\% - 41\%). However, this fraction contains 79\% $\pm 6 \%$ carbohydrate which is slightly lower than the product from the hydraulic press $82 \% \pm 8 \%$ ).

\subsection{Carbohydrate Content}

Based on the ANOVA of carbohydrate content (Table 4) it can be seen that the $\mathrm{NaOH}$ concentration and the interaction between the concentrations of $\mathrm{Na}_{2} \mathrm{~S}_{2} \mathrm{O}_{5}$ $\mathrm{NaOH}$ affect the amount of carbohydrate obtained. Since
Table 2. Results of the experimental runs.

\begin{tabular}{ccccc}
\hline Run & $\begin{array}{c}\text { Fiber } \\
\%\end{array}$ & $\begin{array}{c}\text { Ash } \\
\%\end{array}$ & $\begin{array}{c}\text { Carbohydrate } \\
\%\end{array}$ & $\begin{array}{c}\text { Yield } \\
\%\end{array}$ \\
\hline 1 & 3.7 & 4.0 & 76.0 & 14.1 \\
2 & 2.4 & 1.9 & 76.4 & 33.7 \\
3 & 2.9 & 0.7 & 76.9 & 49.7 \\
4 & 1.6 & 1.0 & 82.2 & 35.0 \\
5 & 3.3 & 1.5 & 82.0 & 40.7 \\
6 & 2.7 & 1.5 & 74.5 & 44.0 \\
7 & 2.0 & 2.7 & 88.9 & 31.7 \\
8 & 2.6 & 1.6 & 82.1 & 40.9 \\
9 & 3.8 & 3.8 & 92.0 & 64.9 \\
10 & 2.4 & 3.5 & 88.7 & 47.0 \\
11 & 1.9 & 1.3 & 94.0 & 31.5 \\
12 & 2.5 & 1.3 & 81.3 & 35.1 \\
13 & 3.2 & 2.0 & 82.3 & 43.2 \\
14 & 2.3 & 2.9 & 76.7 & 25.2 \\
15 & 2.8 & 1.7 & 73.8 & 33.9 \\
16 & 3.2 & 2.3 & 77.0 & 57.6 \\
17 & 2.5 & 1.2 & 74.2 & 35.0 \\
18 & 2.9 & 3.0 & 81.1 & 11.1 \\
19 & 2.7 & 4.3 & 66.5 & 30.0 \\
20 & 2.7 & 2.7 & 81.8 & 34.6 \\
21 & 3.2 & 3.6 & 75.4 & 45.7 \\
22 & 1.4 & 0.4 & 82.7 & 39.0 \\
23 & 2.6 & 0.5 & 78.7 & 37.4 \\
24 & 2.4 & 2.6 & 93.6 & 30.4 \\
25 & 3.2 & 1.0 & 77.7 & 39.2 \\
26 & 1.4 & 0.7 & 65.1 & 38.7 \\
\hline
\end{tabular}

Table 3. ANOVA for starch yield response.

\begin{tabular}{cccccc}
\hline Factor & SS & DF & MS & F Value & p-Value \\
\hline$\left[\mathrm{Na}_{2} \mathrm{~S}_{2} \mathrm{O}_{5}\right]$ & 144.47 & 1 & 144.47 & 3.38 & 0.18 \\
{$[\mathrm{NaOH}]$} & 0.24 & 1 & 0.24 & 2 & 0.95 \\
Treatment & 442.65 & 1 & 442.65 & $3.37 \mathrm{E}-003$ & 0.02 \\
\hline
\end{tabular}

Table 4. ANOVA for carbohydrate content response.

\begin{tabular}{cccccc}
\hline Factor & SS & DF & MS & F Value & p-Value \\
\hline $\mathrm{A}:\left[\mathrm{Na}_{2} \mathrm{~S}_{2} \mathrm{O}_{5}\right]$ & 22.39 & 1 & 22.39 & 0.69 & 0.42 \\
$\mathrm{~B}:[\mathrm{NaOH}]$ & 204.67 & 1 & 204.67 & 6.28 & 0.02 \\
Treatment & 62.86 & 1 & 62.86 & 1.93 & 0.18 \\
$\mathrm{AB}$ & 165.91 & 1 & 165.91 & 5.09 & 0.04 \\
$\mathrm{BC}$ & 132.74 & 1 & 132.74 & 4.07 & 0.06 \\
\hline
\end{tabular}

the $\mathrm{p}$-value of $\mathrm{BC} \approx 0.05$, so it can be predicted that there is a relation between the physical treatment and the additive $(\mathrm{NaOH})$.

From Figure 1, it can be seen that at the high concentration of $\mathrm{Na}_{2} \mathrm{~S}_{2} \mathrm{O}_{5}$ and the high concentration of $\mathrm{NaOH}$, within the selected ranges of this research the carbohydrate content reached the maximum value.

However, if the 3D surface plot is observed for each physical treatment (Figures 2 and 3), the effect of concentration of additives on the carbohydrate content gives a different profile. The separation process using the screw 


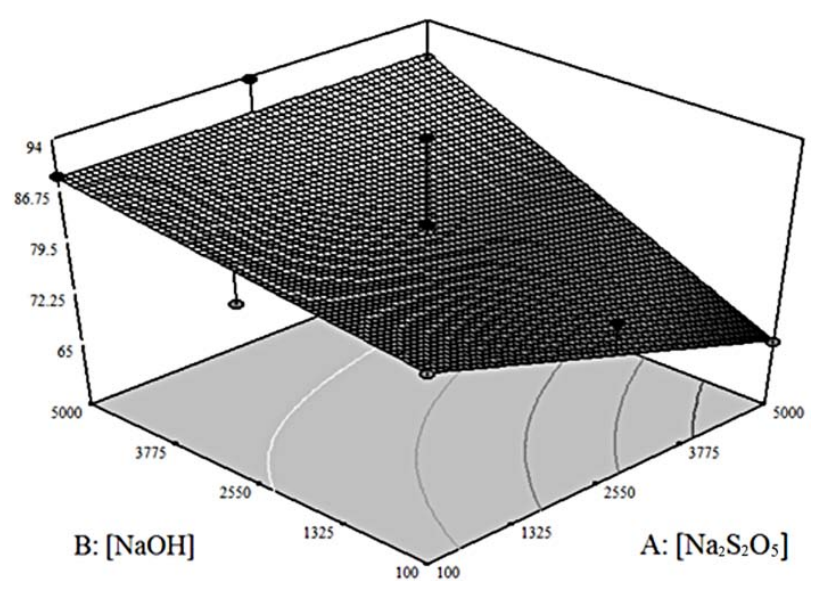

Figure 1. 3D plot of carbohydrate content.

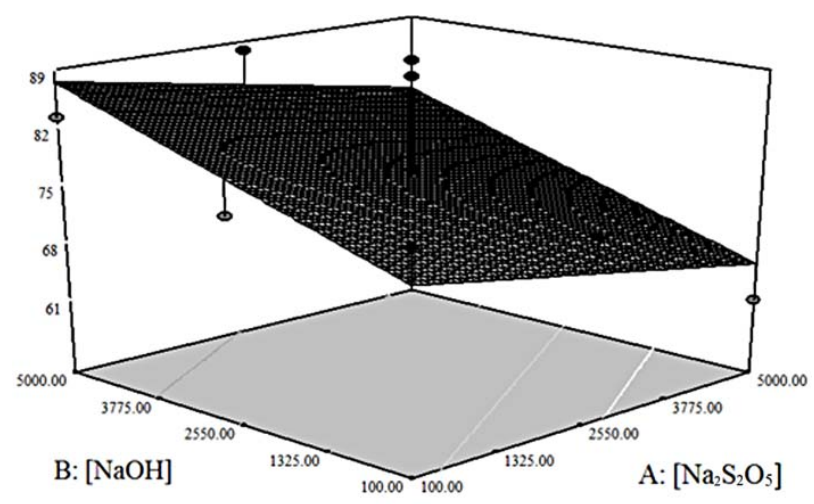

Figure 2. 3D surface of carbohydrate content using the hydraulic press.

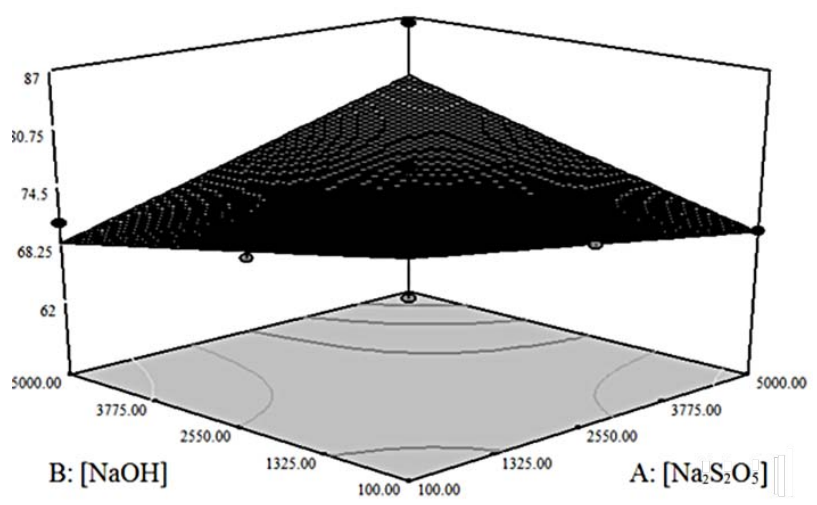

Figure 3. 3D surface of carbohydrate content using the screw press.

press is slower than the hydraulic press. This results in the need for the higher concentration of Na-metabisulphite (5000 ppm) to achieve high carbohydrate content as well as to prevent microbial growth in the slurry which can destroy the carbohydrate. This is a different result compared to the hydraulic press in which it is enough to use $100 \mathrm{ppm}$ to gain a high carbohydrate yield.

The models resulting from the statistical methods illu- strate the relation between the carbohydrate content and the significant factors as followed:

For the hydraulic press

$$
\begin{aligned}
\mathrm{CC} & =83.2-3.7 \times 10^{-3}\left[\mathrm{Na}_{2} \mathrm{~S}_{2} \mathrm{O}_{5}\right]+1.1 \times 10^{-3}[\mathrm{NaOH}] \\
& +7.6 \times 10^{-7}\left[\mathrm{Na}_{2} \mathrm{~S}_{2} \mathrm{O}_{5}\right][\mathrm{NaOH}]
\end{aligned}
$$

For the screw press

$$
\begin{aligned}
\mathrm{CC}= & 81.1-1.3 \times 10^{-3}\left[\mathrm{Na}_{2} \mathrm{~S}_{2} \mathrm{O}_{5}\right]+1.6 \times 10^{-3}[\mathrm{NaOH}] \\
& +7.6 \times 10^{-7}\left[\mathrm{Na}_{2} \mathrm{~S}_{2} \mathrm{O}_{5}\right][\mathrm{NaOH}]
\end{aligned}
$$

\subsection{Fiber Content}

Based on the ANOVA calculations (see Table 5), the additives concentration, both $\mathrm{Na}_{2} \mathrm{~S}_{2} \mathrm{O}_{5}$ and $\mathrm{NaOH}$ do not affect the reduction of fiber content. This is also proved by the $\mathrm{P}$ values for both additives $(>0.05)$. So, the physical treatment determines the amount of fiber in starch after extraction. This result is the same as for the starch yield.

\subsection{Ash Content}

Ash content shows the presence of inorganic component in the starch. These can originate from the rhizome, but also from the chemicals added during processing. From the ANOVA calculations (see Table 6) it can be seen that the concentration of $\mathrm{NaOH}$ and the physical treatment affect the amount of inorganic material left in the starch. This seems due to the solubility level of $\mathrm{Na}_{2} \mathrm{~S}_{2} \mathrm{O}_{5}$ in water which is higher than $\mathrm{NaOH}$.

On Figure 4, it is shown that although $\mathrm{Na}_{2} \mathrm{~S}_{2} \mathrm{O}_{5}$ concentration does not affect the ash content significantly, there is a tendency that the higher concentrations of additives, both $\mathrm{Na}_{2} \mathrm{~S}_{2} \mathrm{O}_{5}$ and $\mathrm{NaOH}$, result in a higher ash content in the starch.

\section{CONCLUSIONS}

This study showed that the integration of physical and chemical is a promising technology for the extraction of starch from Canna edulis. It is a relatively simple and low cost process and it produces a good quality starch.

Table 5. ANOVA for fiber content response.

\begin{tabular}{cccccc}
\hline Factor & SS & DF & MS & F Value & p-Value \\
\hline$\left[\mathrm{Na}_{2} \mathrm{~S}_{2} \mathrm{O}_{5}\right]$ & 0.089 & 1 & 0.089 & 0.41 & 0.5261 \\
{$[\mathrm{NaOH}]$} & 0.43 & 1 & 0.43 & 2.00 & 0.1717 \\
treatment & 4.54 & 1 & 4.54 & 21.18 & 0.0001 \\
\hline
\end{tabular}

Table 6. ANOVA for ash content response.

\begin{tabular}{cccccc}
\hline Factor & SS & DF & MS & F Value & p-Value \\
\hline$\left[\mathrm{Na}_{2} \mathrm{~S}_{2} \mathrm{O}_{5}\right]$ & 0.63 & 1 & 0.63 & 1.54 & 0.2284 \\
{$[\mathrm{NaOH}]$} & 20.18 & 1 & 20.18 & 48.80 & $<0.0001$ \\
Treatment & 2.55 & 1 & 2.55 & 6.18 & 0.0210 \\
\hline
\end{tabular}




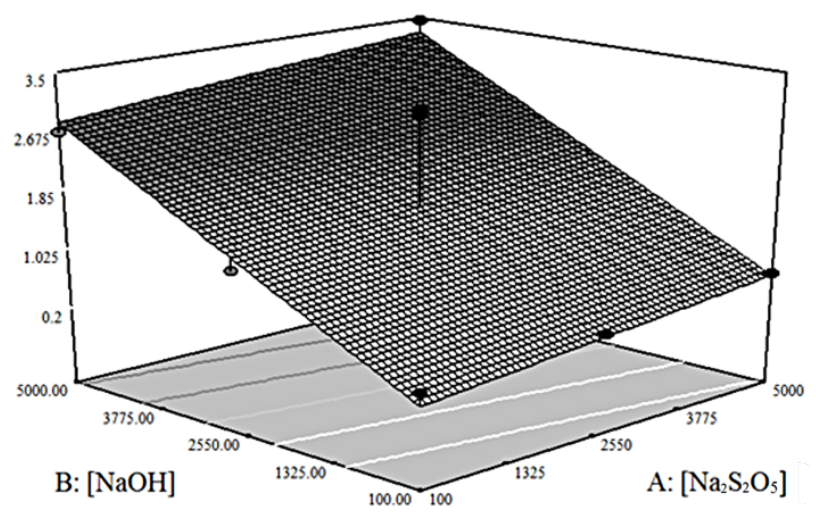

Figure 4. 3D surface of ash content.

The use of the screw press in the separation process of the fibers after the chemical extraction produce gives a higher starch yield compared to the use of hydraulic press, but the purity is lower. Therefore, the hydraulic press is perhaps the most suitable method for preparing starch that has to be a feed material for chemical modification processing.

\section{ACKNOWLEDGEMENTS}

The authors would like to express their thanks to the Indonesian Directorate General of Higher Education-Ministry of Education which finances this research and also the Chemical Engineering fresh graduates of Parahyangan Catholic University: Ricky Gunadi, Pamela and David who assisted the authors in the preparation of this research. Special thanks are addressed to the leader of "Mekar Sari" farmers union Bapak Kemin, who facilitated the collection of the Canna edulis Ker. Rhizome, and Indonesian Institute of Sciences (LIPI, Subang) which allowed us to use their equipment for extracting the starch.

\section{REFERENCES}

[1] Moorthy, S.N. (2002) Physicochemical and functional properties of tropical tuber starches: A review. StarchStärke, 54, 559-592.
http://dx.doi.org/10.1002/1521-379X(200212)54:12<559: :AID-STAR2222559>3.0.CO;2-F

[2] Ganyong (2013) Tanaman Pangan. http://tanamanpangan.deptan.go.id/

[3] Park, S.H., Bean, S.R., Wilson, J.D. and Schober, T.J. (2006) Rapid isolation of sorghum and other cereal starches using sonication. Cereal Chemistry, 83, 611-616. http://dx.doi.org/10.1094/CC-83-0611

[4] Wang, S., Hassani, M.E., Crossett, B. and Copeland, L. (2013) Extraction and identification of internal granule proteins from waxy wheat starch. Starch-Stärke, 65, 186190.

[5] Wang, C., Tian, Z., Chen, L.,Temelli, F., Liu, H. and Wang, Y. (2010) Functionality of barley proteins extracted and fractionated by alkaline and alcohol methods. Cereal Chemistry, 87, 597-606.

http://dx.doi.org/10.1094/CCHEM-06-10-0097

[6] Lim, S., Lee, J., Kyonggi-do, Shin, D. and Lim, H.S. (1999) Comparison of protein extraction solutions for rice starch isolation and effects of residual protein content on starch pasting properties. Starch-Stärke, 51, 120-125. http://dx.doi.org/10.1002/(SICI)1521-379X(199904)51:4 $<120:$ :AID-STAR120>3.0.CO;2-A http://dx.doi.org/10.1002/(SICI)1521-379X(199904)51:4 $<120:$ :AID-STAR120>3.3.CO;2-1

[7] Radosavljevic, M., Jane, J. and Johnson, L.A. (1997) Isolation of amaranth starch by diluted alkaline-protease treatment. Cereal Chemistry, 75, 212-216. http://dx.doi.org/10.1094/CCHEM.1998.75.2.212

[8] Mistry, A.H., Schmidt, S.J. and Eckhoff, S.R. (1992) Alkali extraction of starch from corn flour. Starch-Stärch, 44, 284-288. http://dx.doi.org/10.1002/star.19920440803

[9] Matsunaga, N. and Seib, P.A. (1997) Extraction of wheat starch with aqueous sodium hydroxide. Cereal Chemistry, 74, 851-857. http://dx.doi.org/10.1094/CCHEM.1997.74.6.851

[10] Hedge, J.E. and Hofreiter, B.T. (1962) Carbohydrate chemistry 17. Whistler, R.L. and Be Miller, J. N., Eds., Academic Press, New York. 